\title{
The Dynamics of Russia's Response to the Piracy Threat
}

\author{
Simon Saradzhyan ${ }^{*}$
}

\section{Introduction}

Russia's Maritime Doctrine describes "maritime shipments" as being of "vital importance" to the country. Maritime shipments have accounted for 60 percent of Russia's foreign trade shipments in the recent years. However, vessels bearing the Russian flag account only for 4 percent of Russia's foreign trade shipments. ${ }^{1}$ And the Russian fishing fleet remains relatively near to Russia's shores, not venturing into the Indian and South Pacific Oceans.

This helps to explain why Russian vessels account for only a small fraction of the ships annually victimized by piracy and other armed attacks directed at vessels, registered by the International Maritime Bureau. ${ }^{2}$

There are no Russian government statistics on the number of attacks on Russian crews or vessels in the public domain, although Russian government officials have re-

Simon Saradzhyan is a research fellow at Harvard Kennedy School's Belfer Center. His research interests include nuclear and conventional terrorism, arms control, U.S.-Russian relations, defense, security and space affairs in Russia and other newly-independent states. Prior to joining the Belfer Center, Saradzhyan worked as a researcher for East West Institute and as a consultant for the United Nations Office for the Coordination of Humanitarian Affairs (OCHA), conducting field research and co-writing a scenario-planning report on the situation in the North Caucasus. Simon has also worked as deputy editor of the Moscow Times and as Moscow correspondent for Defense News. Saradzhyan is the author of a number of papers on terrorism and security. He has presented his research at numerous conferences.

1 According to the 2006-2010 Strategy of Development of Transport of the Russian Federation, endorsed by the government in July 2006.

2 This article partially relies on the definition of piracy as given in the High Seas Convention and the Law of the Sea Convention (LOSC). "Piracy now requires six specific elements. The act must: (i) be illegal; (ii) be committed by a private ship or aircraft (or a public craft if the crew has mutinied); (iii) be against another ship or aircraft; (iv) be in an area outside the jurisdiction of any State (usually, the [High Seas]); (v) be for private ends; and (vi) result in the detention of the craft or violence or depredation directed at the craft, its passengers or crew, or their property." The limiting requirement that there be an "illegal act" seems to permit acts of a piratical nature to take place with color of right, as during a war. Interestingly, the LOSC leaves the matter of determining the nationality of pirate ships to domestic laws on ship nationality. Presumably, some states' laws may decree that an act of piracy strips the ship of its nationality and thus eliminates that state's international responsibility for the acts of the pirate ship. As the LOSC's definition refers only to incidents on the high seas, the article's definition of piracy also includes the term "armed attacks" to describe similar acts that take place in territorial waters. 
peatedly noted that the number of such attacks has increased in the past several years. ${ }^{3}$ The Russian press has reported that the number of attacks by pirates on Russian vessels increased in the aftermath of the break-up of the Soviet Union, peaking at twenty-eight incidents in 1993, before decreasing in the late 1990s. ${ }^{4}$ The record for the number of Russian citizens to be seized by pirates in one attack was set in November 2009, according to one Russian media report, when as many as twenty-three Russian citizens were on board the Thai Union fishing vessel, which was seized by Somali pirates. ${ }^{5}$

Overall, however, the odds that any of Russia's some 6,400 civilian shipping or fishing vessels or Russian crew members of foreign ships will be seized by pirates remains very low.

Some 25,000-35,000 ships pass through the Gulf of Aden per year, with only dozens being hijacked, and only several of these being vessels with Russian crew members and/or owners, according to Sea Bulletin-Sovfreight, a respected Russian commercial shipping news outlet. ${ }^{6}$

These low odds help to explain the fact that, until the fall of 2008, Russia did not employ any naval assets to fight piracy. The financial difficulties experienced by the Russian Navy in the aftermath of the break-up of the Soviet Union also help to explain this lack of a response, as has done, until recently, the low level of public awareness and interest in the issue in Russia.

This article begins by outlining the laws that regulate Russian governmental agencies' responses to piracy. It then describes the dynamics of the practical response of the Russian Defense Ministry and other government agencies to this threat before noting the danger of the potential nexus between piracy and terrorism. The article then concludes with an explanation of why the piracy may be elevated higher in the hierarchy of threats to national security as seen by Russian authorities, and offers selected general recommendations.

\section{Russian Authorities' Responses to Piracy: Legal Dimensions}

The counter-piracy and counter-terrorism powers of Russian governmental agencies are defined by a number of international and national laws. These laws include the Convention for the Suppression of Unlawful Acts against the Safety of Maritime Navigation, the United Nations Convention on the Law of the Sea, the Criminal Code, the Law on Defense, the Federal Law on Countering Terrorism, and the Federal Regula-

3 See for instance, a statement by the Russian Navy spokesman Igor Dygalo: "The increase in pirate attacks on Russian and foreign vessels reaffirms the rightness of the course chosen by the Russian military leadership ... for revival of the Russian military presence in the World Ocean." "The Russian Navy Calls on All Countries to Unite Against Piracy," Izvestia (27 May 2008).

4 “Where Ours Have Not Gone Missing," Kommersant (12 January 2000).

5 "Fateful Tuna: Somali Pirates Have Kidnapped a Record Number of Russians," Novye Izvestia (2 November 2009).

6 "Piracy in Year 2010: Marines Are the Only Hope," Sea Bulletin-Sovfreight (6 January 2010). 
tions on the System of Protection of Maritime Navigation from Unlawful Acts against the Safety of Maritime Navigation.

The international anti-piracy legal regime has several loopholes, which pirates successfully exploit, according to the Russian Navy's analysis of this document. ${ }^{7}$ The law bars navies of foreign countries from pursuing pirates in those straits where international passage of vessels is allowed, but which are within territorial waters of a third country, according to a statement issued to the author by the Russian Navy in response to written questions on Russia's response to maritime piracy and terrorism. ${ }^{8}$ The only action that the Russian Navy can take in such a case is to notify this third country that a vessel has been seized by pirates in such straits. ${ }^{9}$ The pirates take advantage of this "loophole" by, for instance, staging an attack in the territorial waters of one country and then fleeing to the territorial waters of another country, according to the Russian Navy's interpretation of the convention..$^{10}$

There is one geographical area where this loophole has been closed. In May 2008, the United Nations Security Council (UNSC) passed a resolution to allow navies of foreign countries to enter the territorial waters of Somalia to free crews of vessels hijacked by pirates and pursue the pirates themselves, provided that these countries sign formal treaties with the government of Somalia to do so. Somalia's Ambassador to the Russian Federation Muhammed Khandulle even claimed in October 2008 that his government would grant the Russian military the permission to pursue pirates not only in Somali territorial waters, but also on land. ${ }^{11}$ The envoy also claimed that his government is negotiating with Moscow to have Russian forces perform Coast Guard functions in Somalia's pirate-infested waters. ${ }^{12}$ Both claims later turned out to be unfounded.

On 16 December 2008, the UNSC adopted another resolution, authorizing countries and multinational organizations involved in tackling piracy to "undertake all necessary measures in Somalia, including in its airspace" to prevent "acts of piracy and armed robbery at sea." ${ }^{13}$ And in January 2009, Russia joined twenty-three other nations and five international organizations to form the Contact Group on Piracy off the Coast of Somalia at the United Nations to strengthen efforts to thwart piracy in the region of the Horn of Africa. ${ }^{14}$

But while activities in the UN, including UNSC resolutions, help to fill some of the legal vacuum identified by the Russian Navy as a hurdle in countering piracy, other

7 From a written statement issued to the author by the Russian Navy in response to his written questions on Russia's response to maritime piracy and terrorism (29 March 2008).

8

9 Ibid

10 Ibid.

11 Interfax (15 October 2008).

12 Gazeta.ru (15 October 2008).

13 "Russian Cruiser Pyotr Veliky Leaves India," RIA Novosti (31 January 2009).

${ }^{14}$ Merle D. Kellerhals, Jr., "UN Forms Group to Coordinate Actions against Maritime Piracy," All Africa (16 January 2009). 
hurdles remain, such as where to prosecute captured pirates (given that Somalia is a failed state $)^{15}$ and rules of engagement. ${ }^{16}$ Russia's reluctance to prosecute pirates became evident in May 2009. At the end of that month, Russian authorities decided to pass on ten pirates who had been detained along with their three vessels by the crew of the Pyotr Veliky, a Russian nuclear-powered cruiser, off the coast of Somalia in February 2009. All the ten were citizens of Somalia, but the Russian Navy passed them on to Yemen for prosecution. ${ }^{17}$ Likewise the Russian Navy transferred twenty-nine pirates who had been detained by the crew of the Russian Navy's Admiral Panteleev warship in April 2009, for prosecution in Iran and Pakistan. These pirates included citizens of Somalia, Iran, and Pakistan. ${ }^{18}$ The Russian authorities could have tried the pirates themselves, as Moscow was given such a right by a resolution passed by the United Nations Security Council in December 2008, ${ }^{19}$ as well as by the United Nations Convention on the Law of the Sea. Russia's national legislation provides for piracy to be punished with sentences ranging between four and fifteen years in prison and a fine of up to 500,000 rubles (about USD 17,000). The sentence could be significantly longer if the act of piracy is aggravated by hostage taking and/or other grave crimes, according to Russia's Criminal Code.

However, the Russian authorities chose not to prosecute pirates, perhaps to avoid the costs of prosecution and incarceration as well as the hassle associated with the entire process. When the twenty-nine pirates were still in custody, the Russian media reported that they became "boarders" on the Admiral Panteleev. ${ }^{20}$ The official rationale, however, as outlined by Deputy Prosecutor General Alexander Zvyagintsev, was that there has been no precedent of when pirates who have caused no damage to Russia or its citizens but were arrested by Russian authorities would be tried in Russia. ${ }^{21}$

The two incidents did get Russian authorities thinking on how to finesse the nation's legal response to piracy. President Dmitry Medvedev tasked the Prosecutor

15 "When we capture a pirate, where do we take him? Where do we hold him?" Gortney said. "What court system tries him and holds him? If they're found guilty, [how do we] hold them accountable for their actions?" Vice Adm. William Gortney, the commander of U.S. Naval Forces Central Command, told reporters at a 15 January 2009 Pentagon briefing. "Process for Capture, Accountability Remains Piracy's Challenge," Inside the Navy 22:3 (26 January 2009).

16 "U.S. Admiral Mark Fitzgerald said in October 2009 that, while he was aware of where the pirates were operating, there was little he could do militarily to stop them, and that guidelines on how to take them on-including whether to shoot-were still in the works. 'You know, I don't think we've gotten the rules of engagement yet from NATO,' Fitzgerald told reporters on Monday during a briefing on U.S. naval operations in Europe and Africa." Luke Baker, "Navy Commander Admits: No Rules on Somalia Pirates," Reuters (21 October 2008).

17 "Russian Navy Servicemen Got Rid of Pirates," Tyumenskaya Linia (28 May 2009).

18 Ibid.

19 “Russian Cruiser Pyotr Veliky Leaves India,” RIA Novosti (31 January 2009).

20 "Boarders Eat Round Pacific Fleet," RIA Prima Media (30 April 2009).

21 "Deputy Prosecutor General Alexander Zvyagintsev: An International Tribunal for Piracy Is Needed," Izvestia (29 May 2009). 
Generals' Office on 4 May 2009 with drafting a proposal on the prosecution of pirates that would include an option for their international prosecution. Responding to this assignment, Zvyagintsev suggested in late May 2009 that an international tribunal be set up for pirates. When arguing for such a tribunal, the prosecutor noted that it was Russia's right - not its obligation - to put arrested pirates on trial, while their extradition to Somalia would be senseless, since it is a failed state. ${ }^{22}$ Also as part of the response to Medvedev's assignment, the Investigative Committee at the Prosecutor General's Office adopted internal regulations that require the presence of federal investigators in every Russian naval group that is assigned to fight piracy. Head of the Investigative Committee Alexander Bastrykin stated on 3 July 2009 that the regulations enabled his subordinates assigned to the naval groups to open and investigate criminal cases against pirates as well as to send their cases to Russian courts. ${ }^{23}$

Medvedev, however, ended up choosing the international prosecution option. "You know, in this context there are two options of handling them: first ... throw them overboard and that is it. The other option is to bring pirates to justice," Medvedev told Russian naval servicemen who had just returned from an anti-piracy mission off Somalia on 13 July 2009. Medvedev told the servicemen that an international piracy tribunal would be "the best approach," because in many cases both pirates and victims are citizens of several countries, and some of these countries "may be unwilling to bring them to justice." He also argued that "the large number of pirates" cannot be explained by anything other than the direct assistance of the authorities there, because pirates simply cannot be so numerous unless they enjoy a broad support. ... Two or three pirate teams may possibly operate on their own. But if piracy turns into a business that has been in effect for months and that brings in a lot of money, it is clearly part of a corrupt scheme managed by one or even more than one country. This is why I think the international court is the perfect forum in which to adjudicate these matters," Medvedev said. $^{24}$

In November 2009, Medvedev officially announced that Russia would pursue the establishment of such a tribunal through the UN. "As a permanent member of the UN Security Council and participant in various international groups and organizations, Russia supports the drafting of coordinated action measures, including the establishment of a separate criminal court to try piracy cases," Medvedev said. The Russian leader noted, "We are witnessing a real explosion in piracy. This is essentially just as much a global challenge as terrorism and drugs trafficking." 25

Russia's national legislation requires that the authorities first try to employ diplomatic methods to free ships and crews seized by pirates. If diplomatic methods fail, then the President of the Russian Federation has the power to issue an executive order to conduct an anti-terrorist operation outside the borders and territorial waters of the

Ibid.

23 "Somali Pirates Will be Tried in Russia," Nakanune.ru (3 July 2009).

24 "Beginning of Meeting with Navy Servicemen Who Participated in Anti-Piracy Operations off the Coast of Somalia," Kremlin.ru (13 July 2009).

25 "Meeting with Transport Ministers from 24 Countries," Kremlin.ru (20 November 2009). 
Russian Federation, according to a recent statement on piracy issued by the Russian Ministry of Transport. ${ }^{26}$

Such operations are conducted in accordance with the Federal Law on "Countering Terrorism," according to the statement. ${ }^{27}$ Both the Russian Navy and the Ministry of Transportation maintain that this law, which gives the military and law enforcement agencies vast powers, should be applied in cases of piracy both inside and outside of Russia's territorial waters. ${ }^{28}$ The Russian military would prefer to use the anti-terrorist powers vested to them by this 2006 law to fight piracy because the "line between piracy and maritime terrorism has already become blurred," and therefore the challenges of fighting piracy should be bundled together with those of fighting terrorism, according to the Russian Navy. ${ }^{29}$ The 2006 law allowed for the use of the armed forces and other units abroad to fight terrorism. According to the law,

If maritime or river vessels do not react to commands and/or signals to stop violating the rules of use of waters of the Russian Federation (as well as underwater), or refuse to obey demands to stop, then weaponry of naval ships (warplanes) of the Armed Forces of the Russian Federation are used to coerce the vessel to stop in order to eliminate the threat of act of terrorism. ... If the vessel doesn't stop, doesn't obey orders and/or it is impossible to coerce the vessel to stop and if all the measures, which could be taken to try stop it in this situation, have been exhausted, and there is a real threat to human lives or an ecological catastrophe, then weaponry of the naval ships (warplanes) of the Armed Forces of the Russian Federation shall be used to end movement of this vessel by its destruction.

To further strengthen the government's capacity for action, the Russian Parliament passed and the president signed into law a set of amendments to the Law on Defense. These amendments allow the president to deploy units of the armed forces on missions abroad, including counter-piracy missions, without consent of the parliament.

Significantly, however, Russia's new Strategy of National Security Until Year 2020, which President Medvedev signed off in May 2009 on, contains no references to piracy.

In the meantime, the strategic guidelines for the Russian authorities' responses to piracy are formulated in the Maritime Doctrine of the Russian Federation for Years 2001-2020. Apart from assigning classical military functions to the navy, this doctrine requires the Russian Navy to "create and sustain conditions ... for [the] maritime economic activities of the Russian Federation in the World Ocean ... and [the] presence of the Russian Federation in the World Ocean."

26 Statement on Russia's response to maritime piracy and terrorism by the Ministry of Transport of the Russian Federation issued to the author in response to his written questions (3 April 2008).

27 Ibid.

28 Ibid.; statement to the author by the Russian Navy in response to written questions on Russia's response to maritime piracy and terrorism (29 March 2008).

29 Statement to the author by the Russian Navy in response to written questions on Russia's response to maritime piracy and terrorism (29 March 2008). 
The doctrine also calls for the "presence of the Russian Fleet in far flung areas of the World Ocean," but does not explicitly delineate the global posture of the Russian Navy. The doctrine does list ensuring the "sovereignty of the Russian Federation in inner seas, territorial seas as well as in airspace above it and at the bottom under it" as the Russian military's main priorities at sea.

The doctrine also calls for the deployment of "sufficient naval potential and its efficient use in case use of force is needed to support the state's actions." At the same time, the doctrine only briefly mentions piracy as a threat that Russian ships should be aware of, and only in one part of the world's seas: the Indian Ocean. The doctrine calls for "more active cooperation with countries of the Asia-Pacific region aimed at ensuring safety and security of maritime navigation and fight against piracy."

In comparison, the Russian Navy's own assessment of the global threat of piracy as of 2008 designates the following areas of the world as prone to piracy: ${ }^{30}$

- $\quad$ East Africa (Somalia, India, Sri Lanka, Bangladesh, and Tanzania)

- West Africa (Nigeria, Senegal, Angola, Ghana)

- Indian Ocean

- South East Asia and the South China Sea (Malacca Strait, Indonesia, Philippines, Thailand)

- South America and the Caribbean (Brazil, Colombia, Venezuela, Ecuador, Nicaragua, Guyana).

The most recent strategic document to regulate the Russian state's response to piracy is the new Military Doctrine. The doctrine, which President Dmitry Medvedev approved after a number of delays in February 2010, lists "fighting piracy, ensuring security of maritime shipping," and "ensuring security of the economic activities of the Russian Federation in the World Ocean" among the armed forces' peacetime missions. ${ }^{31}$ In comparison, the 2000 military doctrine contained no references to piracy.

\section{Practical Responses to Piracy}

\section{Military Response}

The Russian Navy is "the most efficient instrument" in the government's toolbox to respond to piracy and other armed attacks at seas, according to the Russian Navy's March 2008 statement. ${ }^{32}$ But the force's counter-piracy potential has been constrained by material problems that emerged after the dissolution of the Soviet Union.

In the Soviet era, the national armed forces maintained a global posture, which allowed the Russian Navy to react promptly whenever pirates attacked Soviet commer-

30 Ibid.

31 "Military Doctrine of the Russian Federation," 5 February 2010; available at http://news.kremlin.ru/ref_notes/461 (in Russian).

32

Statement issued to the author by the Russian Navy in response to written questions on Russia's response to maritime piracy and terrorism (29 March 2008). 
cial ships. In one instance in the late 1960s, a group of Soviet warships sailed to the coast of West Africa to free two tugboats that had been seized off the coast of Ghana. The boats were promptly released upon the arrival of the Soviet naval group. ${ }^{33}$ In another case, the Soviet Navy's minesweeper Razvedchik successfully fought off an attack by ships of then-Eritrean "separatists" on the Soviet cargo ship International in the Red Sea off the coast of Ethiopia in May 1990. In the same area, the patrol craft $A K-213$ waged a twenty-four-hour battle against four fast patrol boats operated by these separatists, sinking three of them. ${ }^{34}$

The Russian Navy - as was the case with the rest of the armed forces-saw its budgets plummet with the disintegration of the Soviet Union.

Faced with a lack of cash, the military-political leadership decided to focus on financing the strategic nuclear forces, which they saw as the main deterrent and equalizer of the weakness of Russia's conventional forces vis-à-vis the U.S. and NATO.

As recently as 2007, construction of Project 955 and 955A atomic submarines consumed 70 percent of all funds allocated for the construction of warships by the Russian Navy. ${ }^{35}$

Until recently the navy's command have made no secret of the dire straits that the conventional forces may soon find themselves in. Then-commander of the Russian Navy Adm. Vladimir Kuroyedov admitted in February 2005 that the navy would have to begin "massive and irreversible" decommissioning of warships after 2010 in a move that would leave the navy with about fifty combat warships in the country's Black Sea, Baltic, Northern, and Pacific Fleets as well as in the Caspian Sea flotilla by $2020 .^{36}$

In addition to its own ships, the Russian Navy can also rely on the Border Guard Service's Coast Guard units for assistance in operations to interdict armed attacks on ships in Russia's own territorial waters. These Coast Guard units are tasked with the challenge of protecting Russia's water frontiers, which span over 46,000 kilometers, including 39,000 km of sea frontiers. However, Coast Guard ships are designed for littoral waters and, therefore, cannot be used for counter-piracy operations off the coast of Africa and other areas located at a significant distance from Russia.

The Soviet Navy used to maintain bases in Cuba, Poland, Finland, East Germany, Egypt, Yemen, Libya, Somalia, and Ethiopia at one time or another. Some of these bases were shut down during the Soviet period, while others were closed after break-up of the Soviet Union. Among those shut down after 1990 was a key base in Vietnam's Cam Rahn Bay. The base had a landing strip as well as naval repair and maintenance facilities, which were frequently used by Russian Navy groups that operated in the Pacific and Indian Oceans during the Cold War. The Russian Navy's current list of overseas facilities includes only a repair facility in Tartus on Syria's Mediterranean Sea

\footnotetext{
33 Russian edition of Newsweek (11-17 February 2008).

34 "Chornaya Metka Ot Spetznaza," Rossiiskaya Gazeta (2 December 2008); translated by BBC Monitoring (10 December 2008).

35 "Kuda Idyot Voyennyi Flot," Vlast (25 February 2008).

36 Ibid.
} 
coast, a naval equipment testing facility in Kyrgyzstan, as well as facilities in Vileiki, Belarus; Bishkek, Kyrgyzstan; and Havana, Cuba.

The sharp increase in Russia's budget revenues, fuelled by high oil and gas prices around the world, have allowed the Russian government to increase defense expenditures. Russia's defense spending skyrocketed from USD 5 billion in 2000 to USD 40 billion in $2008 .^{37}$ Military spending was to further increase by 26 percent in 2009 , bringing it to 1.3 trillion rubles (about USD 50 billion), its highest level since the collapse of the Soviet Union. ${ }^{38}$

The global economic crisis forced Russia to revise its defense expenditures in 2009, but Prime Minister Putin vowed in February 2009 that defense procurement would be fully financed that year. The economy began to show signs of stabilization in the fourth quarter of 2009, and began to grow in 2010, which may allow the government to keep its pledge to spend a total of USD 140 billion on defense procurement from $2009-11 .^{39}$

These budget hikes have allowed the Russian Defense Ministry to start eyeing the re-establishment of some of its naval bases abroad. An unidentified Russian Navy official told a government news agency in January 2009 that a "political decision has been made to create" permanent bases in Yemen, Syria, and Libya. ${ }^{40}$ Of the three, the base in Yemen would be most convenient for supporting anti-piracy missions.

Speaking to reporters in the same month, then-Deputy Chief of the General Staff of the Russian Armed Forces Col. General Anatoly Nogovitsyn confirmed that Russia is negotiating development of naval bases with several foreign countries, but did not name any. ${ }^{41}$

In June 2009, the Russian media reported that the Russian Defense Ministry "made a decision" to expand and modernize the Tartus facility, which the Russian Navy rents from Syria. One of the reasons for the modernization was to ensure that Russian warships en route to the Gulf of Aden for piracy missions are properly serviced and supplied. $^{42}$

In addition to negotiating the re-opening of bases, the federal government has also channeled some of its increased revenues to incrementally increase naval patrols around the world, featuring its only aircraft carrier, the Admiral Kuznetsov and the

37 Andrew Osborn, "World News: Moscow Will Boost Defense Spending to \$50 Billion - Conflict in Georgia Exposed Deficiencies of Aging Arsenal," Wall Street Journal (20 September 2008).

38 Ibid. These ambitious plans were set in early 2009 for revision as prices for oil, which together with gas finances 60 percent of Russia's federal budget expenditures, continued to plummet in early 2009 .

39 The arms-procurement order for 2009-11 will cost USD 140 billion ("nearly four trillion rubles") Vladislav Putilin, deputy head of the military-industrial committee, said in December 2009. "Russia Orders 70 Strategic Nuclear Missiles by 2011: Report," AFP (22 December 2008).

40 ITAR-TASS (16 January 2009).

41 Ibid.

42 "Russian Base for Fighting Pirates," Nezavismoye Voyennoye Obozrenie (24 July 2009). 
flagship of the Northern Fleet, the nuclear battle cruiser Pyotr Veliky. The Admiral Kuznetsov led a group of Northern Fleet warships on a voyage into the Atlantic and Mediterranean from 4 December 2007 - 3 February 2008. The battle group participated in a joint anti-terrorism exercise with warships of the French and Italian Navies. 2008 also saw the Russian Navy send a group of warships to Latin America, where they participated in a joint exercise with Venezuela's navy. "The process of the return to the World Ocean has already begun," Adm. Vladimir Vysotsky, commander of the Russian Navy, proclaimed in April 2008. ${ }^{43}$

But while it has been sailing the waters of the Mediterranean and the Atlantic, the Russian Navy has until recently stayed away from what Adm. Vysotsky would have described as a "problematic" area: the waters off Somalia, where most of the world's recent incidents of piracy and armed attacks have occurred.

This area saw as many as 26 vessels attacked by pirates between January and May of 2008 compared to a total of 31 attacks registered in 2007. Seas off the coast of Somalia accounted for 11 out of 18 vessels seized by pirates in 2007, according to the International Maritime Bureau. Increased activities of pirates in waters off Somalia and Nigeria accounted for a 10 percent increase in the overall number of piracy-related incidents in 2007. That year there were 263 instances of pirates attacking sea vessels registered compared to 239 such incidents in 2006. Pirates opened fire in 72 cases in 2007, killing 5 crew members and wounding 64. In comparison 17 crewmembers were wounded and none killed in 2006. The waters off Somalia, including the Gulf of Aden, are the world's most dangerous, accounting for 63 - or nearly a third - of the 199 reported pirate attacks worldwide between January and September 2008, according to the International Maritime Bureau. The types of attacks, the violence associated with them, the number of hostages taken and the amounts paid in ransom have all also increased, according to a report released by the agency's piracy reporting center in Kuala Lumpur. ${ }^{44}$

In 2008, Somali pirates demanded ransoms totaling USD 150 million in exchange for the release of seized ships, including at least one ship with several Russian crew members, according to the UN. ${ }^{45}$ The Somali pirates are estimated to have actually collected around USD 30 million in ransom in 2008 . $^{46}$

As of early 2009, fourteen ships and some 280 seamen from twenty-five nations were being held hostage in Somalia, including at least one ship with Russian crewmembers. Two seamen were killed in attacks in 2009, according to the International Maritime Organization. ${ }^{47}$

43 Nezavisimoye Voyennoye Obozrenie (14 April 2008).

44 “Somali pirate attacks up 75 percent this year," $A P, 23$ October 2008.

45 "Russian, Indian Warships Escort Commercial Ships off Somali Coast," RIA Novosti (9 February 2009).

46 Antonio Maria Costa, "Piracy Must be Defeated in Courts, Ports and Banks, not Just at Sea," Lloyd's List (5 February 2009).

47 Kellerhals, Jr., "UN Forms Group to Coordinate Actions Against Maritime Piracy." 
The seizure of the Danish-owned Svitser Korsakov trawler carrying a Russian crew in early 2008 may have contributed to a change in the Russian government's response to piracy. The Danish owners of the Svitser Korsakov explicitly asked the Russian authorities not to interfere, promising to arrange the release of the crew themselves, according to the Russian Navy. The ship and its crew were, indeed, eventually released after the payment of a USD 700,000 ransom.

Nevertheless, the Russian authorities' decision not to intervene generated a flurry of critical reports in the national media, eventually prompting the federal government to respond. Then-First Deputy Premier Dmitry Medvedev—who went on to become Russia's president in May 2008 - asserted that the Russian Navy "should be present" in the seas around the world. Adm. Vladimir Vysotsky, commander of the Russian Navy, also weighed in, vowing, "The Russian Navy will fight against pirates seizing ships in different regions of the world. He also admitted, "Our ships, their crews and cargos need protection, and the recent seizure of the Svitser Korsakov ... is evidence of that. ... The increase in [the] numbers of pirate attacks on Russian and foreign vessels confirm the rightness of the course adopted by the military leadership of the Russian Federation for [the] resumption of [the] presence of Russian warships in all regions of the World Ocean, in regions of intensive fishing and maritime navigation in particular," the commander said. ${ }^{48}$

Later that year, the Russian Navy dispatched the frigate Neustrashimy from its Baltic Sea Fleet to fight piracy in the waters off Somalia. ${ }^{49}$ The missile frigate arrived off the Somali coast in late October 2008. But before this warship could arrive, Somali pirates hijacked the Ukrainian ship Faina, which had three Russians, one Latvian, and seventeen Ukrainians in its crew when it was seized in late September 2008. The captain, a citizen of Russia, died of a heart attack soon after the pirate assault. ${ }^{50}$ A USD 3.2 million ransom had to be paid to secure the release of the ship.

As for the Neustrashimy, it escorted a total of more than fifty commercial vessels through the Gulf of Aden before returning to the Baltic Sea Fleet in 2009. The frigate carried a special commando unit in addition to the marines on board, and some were deployed on board vessel ships that the frigate was escorting. ${ }^{51}$

On 7 January 2009, the frigate was replaced by Russia's Pacific Fleet destroyer the Admiral Vinogradov, which arrived in the Gulf of Aden together with a tugboat and two fuel tankers. ${ }^{52}$ Around that time the Russian Navy also sent the Yamal and Azov of its Black Sea Fleet, which is based in Sevastopol and which Russia leases from Ukraine. Interestingly, both the Yamal and Azov are capable of landing large quantities of vehicles and troops on shore, although Russian commanders have so far made no

48 Nezavisimoye Voyennoye Obozrenie (14 April 2008).

49 Bloomberg (20 November 2008); AP (21 November 2008).

50 "Russian Embassy in Kenya to Give Consular Support to Faina Sailors," ITAR-TASS (6 February 2009).

51 "Chornaya Metka ot Spetznaza," Rossiiskaya Gazeta (2 December 2008); translated by BBC Monitoring (10 December 2008).

52 “Russian Navy Denies Somalia Mission Scurvy Claims," RIA Novosti (9 February 2009). 
commitment to pursue pirates on land. ${ }^{53}$ Interestingly, Russia's Ambassador to NATO, Dmitry Rogozin, has acknowledged a need for a land operation. In November 2008 he called for an international ground military operation in the region to crush piracy, but indicated that Russia may not participate. "It's up to the European Union, NATO, and others to launch a coastal land operation to eliminate the pirates," Rogozin said. "Naval action alone will not be enough to liquidate the threat of piracy."

The group of warships led by the Admiral Vinogradov patrolled the waters off Somalia from January 2009 until March 2009. They escorted a total of fifty-four vessels from seventeen countries, detaining a total of twenty-nine pirates before being replaced by the destroyer Admiral Panteleev in April 2009..$^{5}$ It was in April 2009 that Russian admirals and diplomats announced that the Russian Navy would be patrolling the waters off Somalia on a "permanent basis."

The Admiral Panteleev and several other warships patrolled the area from April 2009 to June 2009, escorting one hundred vessels, foiling twenty pirate attacks, and capturing ten pirates. ${ }^{57}$

The Admiral Panteleev group was replaced by a group from the Pacific Fleet, including the destroyer Admiral Tributs, which patrolled the Gulf of Aden from July 2009 through October 2009. This group escorted some one hundred vessels from twenty-six countries. ${ }^{58}$

Also deployed from July to October 2009 were the Northern Fleet's destroyer $A d$ miral Chebanenko and a tanker, which patrolled the area off the Horn of Africa. ${ }^{59}$

A total of ten warships from the Pacific Fleet took part in patrols off the Horn of Africa in 2009. ${ }^{60}$ In January 2010, the Pacific Fleet's destroyer Marshal Shaposhnikov and several other warships left for the Gulf of Aden. ${ }^{61}$

The Russian Navy will retain a permanent presence in the Gulf of Aden and Horn of Arica throughout 2010, according to a January 2010 statement by the force. ${ }^{62}$ Warships from all of Russian Navy's fleets will rotate in the area. ${ }^{63}$

53 "Russia Sends More Warships to Fight Somali Pirates: Report," AFP (16 January 2009).

54 Glenn Bownes, "Russia Calls for 'Ground Operation' to Crush Piracy," Cape Times (21 November 2008).

55 "A Group of Pacific Fleet Ships Returned to Vladivostok After Patrolling the Gulf of Aden," ITAR-TASS (16 November 2009).

56 "Ships of Russian Navy Will Maintain a Permanent Presense Off the Coast of Somalia," Fontanka.ru (14 April 2009).

57 "Pacific Fleet Is to Send the $4^{\text {th }}$ Group of Warships to the Gulf of Aden," (28 December 2009).

58 "A Group of Pacific Fleet Ships Returned to Vladivostok After Patrolling the Gulf of Aden," ITAR-TASS (16 November 2009).

59 "Pacific Fleet Is to Send the $4^{\text {th }}$ Group of Warships to the Gulf of Aden."

60 "Pacific Fleet Servicemen Implemented the Entire Program of Combat Training in 2009," RIA Vesti (26 November 2009).

61 "Pacific Fleet Is to Send the $4^{\text {th }}$ Group of Warships to the Gulf of Aden."

62 "News of the Navy," official web site of the Russian Navy (12 January 2010).

63 "News of the Navy," official web site of the Russian Navy (19 November 2009). 
Several commanders of the Russian warships dispatched to the Gulf of Aden since Fall 2008 have noted that their onboard helicopters have been the most helpful instruments in their arsenals when it came to interdicting piracy attacks.

In fact, both warships employed their Kamov maritime warfare helicopters in the very first engagements off the African coast. The Neustrashimy employed its helicopter to successfully prevent pirates from commandeering a Danish vessel in November $2008 .^{64}$

The Admiral Vinogradov's helicopter was instrumental in foiling a pirate attack on a Dutch container ship in January 2009. Navy spokesman Igor Dygalo said the Ka-27 helicopter from the Russian warship was on patrol off the Horn of Africa when it fired at three suspected pirate speedboats that were trying to attack the Dutch ship, wounding three suspects. ${ }^{65}$ The boats were then boarded by sailors from the Admiral Vinogradov. ${ }^{66}$

Another effective method used by the Russian Navy to foil pirate attacks is the deployment of marines on commercial ships passing through the Gulf of Aden. Vladimir Pidenko, senior security specialist of Russia's Far Eastern Steamship Line, was the first to report that marines from the Russian Pacific Fleet deployments were taking part in such missions in June 2009. "Our military deploy marines on board of civil vessels, and this method has proved its effectiveness," he said. ${ }^{67}$ Deployments of servicemen on ships rather than patrols is not only effective, but also more cost-efficient compared to the deployment of naval groups, according to Mikhail Voitenko, a renowned Russian maritime shipment expert and editor of Sea Bulletin-Sovfreight. ${ }^{68}$ This news outlet estimated the overall cost of the naval operations in the Gulf of Aden at more than USD 1 billion per year. ${ }^{69}$

While the deployment of the Neustrashimy and subsequent Russian Navy warships to the Gulf of Aden highlighted Moscow's decision to materially contribute to the international cause of fighting piracy, it was what Russian prosecutors insist was a case of piracy in the Baltic Sea that generated the most controversy for the Kremlin. If it were, indeed, a case of piracy and not a cover-up for smuggling (as some suspect), then the hijacking of the Arctic Sea in the Baltic Sea represented the most convincing argument that even the safest shipping routes are no longer immune to this threat. The vessel, which had a Russian crew and had listed Algeria as its official destination, was boarded by masked pirates posing as police near the coast of Sweden on 28 July 2009, according to Russian prosecutors. Moscow's response to what the press described as

\footnotetext{
64 "Russian, British Ships Repel Somali Pirate Attack," AP (12 November 2008).

65 "Pirate Attack in Gulf of Aden Foiled by Russian Warship," St. Petersburg Times (16 January 2009); available at www.sptimes.ru/index.php?action_id=2\&story_id=28017.

66 "Pervyi Boi Admirala," Rossiiskaya Gazeta (15 January 2009).

67 "Servicemen of Pacific Fleet Found an Effective Method of Fighting Pirates," RIA Prima Media (16 June 2009).

68 "Piracy in Year 2010: Marines Are the Only Hope," Sea Bulletin-Sovfreight (6 January 2010).

69 Ibid.
} 
"the first act of piracy in European waters for hundreds of years" $" 70$ was quicker and stronger than during previous such cases that occurred off the coast of Africa. This generated suspicions that the ship, which flew a Maltese flag, was carrying some secret cargo, perhaps S-300 anti-aircraft missiles bound for Iran. Russian officials have denied the reports, and a search of the vessel revealed no secret cargo, only timber. President Dmitry Medvedev ordered the Russian military to find and intercept the ship, which was done in August in an operation that involved not only warships, carrying marines, but also the Russian Air Force. Eight men-including Russians, Estonians, and Latvians - were accused of hijacking the Arctic Sea and charged with piracy and kidnapping. $^{71}$

\section{Russian Military Cooperation with Other Nations in Fighting Piracy}

In light of their limited capabilities, the Russian Navy and the Russian government in general have focused on forging sustainable coordinated action betwen all concerned states in such areas where the threat of piracy is real and imminent.

Given the existing legal constraints, one of the most efficient measures of countering maritime piracy and terrorism is inter-regional and international cooperation, as well as joint counter-piracy exercises, according to the Russian Navy's statement. ${ }^{72}$

The Russian Navy believes such cooperation would benefit from more detailed codification in international treaties and from sustainable implementation of these treaties through permanent mechanisms, such as the Piracy Reporting Center in Kuala Lumpur. $^{73}$

In 2007, the Russian Navy participated in a Russia-NATO interoperability exercise near the Atlantic coast of the United States. The Northern Fleet's Admiral Chebanenko warship represented Russia in that wargame.

Russia's Pacific Fleet has also regularly participated in anti-piracy wargames, playing host to the annual Russian-Indian naval wargame INDRA. In 2007, this wargame was held off the Far Eastern port of Vladivostok, and featured the simulation of a naval response to a maritime terrorism act as well as to acts of piracy. Also in the Pacific, the Coast Guard units of the Russian Border Guard Service and the U.S. Coast Guard have established direct communication links, and cooperate regularly to counter illegal fishing and other crimes.

In addition to wargames, the Russian Navy has been participating in naval operations whose mission is to fight terrorism and WMD proliferation, such as the NATOled operation Active Endeavor in the Mediterranean Sea, which is designed to prevent the transit of terrorist individuals or material between North Africa, the Middle East,

\footnotetext{
70 "Russian Navy Arrests Eight 'Pirates' who Seized the Cargo Ship Arctic Sea," Daily Telegraph (18 August 2009).

71 "Last Arctic Sea Sailors Return to Russia," Agence France Presse (3 November 2009).

72 Statement issued to the author by the Russian Navy in response to written questions on Russia's response to maritime piracy and terrorism (29 March 2008).

73 Ibid.
} 
and Europe. The Russian Navy's Ladny patrol ship participated in this operation in 2007, helping to inspect vessels.

NATO put joint wargames with the Russian military on hold and suspended the NATO-Russia Council in the wake of Russia's military campaign in Georgia, in which Russian troops drove back Georgian forces from the separatist province of South Ossetia in August 2008 and continued into Georgian territory. There was one area, however, where military cooperation between individual NATO members and Russia continued in spite of the rifts between the Western Alliance and Moscow: the waters off Somalia.

Less than three months after the August 2008 war, Russia's Foreign Minister Sergei Lavrov reaffirmed his country's commitment to joint action with the U.S. against piracy. He asserted in October 2008 that Russia would work with the United States and the European Union to fight piracy off the African coast. "Russia aims to prevent pirates from causing mayhem," Lavrov said. "It would be useful to coordinate the naval forces that are deployed."

The aforementioned frigate Neustrashimy operated jointly with U.S and other NATO members' warships through the end of 2009. In spite of the freezing of NATORussia ties and tense relations between Moscow and London, the Neustrashimy's first operation in the area turned out to be a joint effort with a British ship. The Neustrashimy and the British frigate HMS Cumberland joined forces to prevent a cargo ship from being hijacked in the Gulf of Aden in November 2008. Each ship sent up a helicopter against the pirates as they tried to commandeer a Danish vessel. ${ }^{74}$

As for the Neustrashimy's replacement, the Admiral Vinogradov, this destroyer and its support ships operated off the coast of Somalia beginning in January 2009 as part of the Combined Maritime Force, which is based in Bahrain and includes warships from the United States, France, Germany, the Netherlands, the United Kingdom, Denmark, and Italy.

Relations between NATO and Moscow began to thaw only in June 2009, when the first post-Georgia informal meeting of NATO's then-Secretary-General Jaap de Hoop Scheffer and Russian Foreign Minister Sergei Lavrov took place. Significantly, piracy was one of the first issues that was discussed within the framework of the RussiaNATO Council after that meeting. At a July 2009 meeting of this council at the ambassadorial level, the Russian envoy to NATO, Dmitry Rogozin, tabled an official Russian proposal for cooperation against piracy, which included joint naval patrols, assignment of liaison officers to the respective forces, and permanent exchange of information. ${ }^{75}$ During the first meeting of the Russian president with the NATO secretary-general since the August 2008 war, Dmitry Medvedev told Anders Fogh Rasmussen that piracy is one area where Moscow and Brussels can work constructively. "Who could have

74 "Russian, British Ships Repel Somali Pirate Attack," AP (12 November 2008).

75 "Russian Federation Made Concrete Proposals to NATO on Fighting Pirates," Rosbalt (22 July 2009). 
imagined that we would have to jointly react to such a problem as piracy," Medvedev mused in the NATO chief's presence. Rasmussen concurred. ${ }^{76}$

According to the Russian Navy, the fight against piracy could be advanced greatly if international naval groups could be established to fight piracy the same way NATO vessels patrol the Mediterranean with occasional assistance from the Russian Navy to fight WMD proliferation. But such proposals are invariably met with suspicion by coastal states, which, being concerned about maintaining sovereignty over their waters, often think that the deployment of foreign naval ships in their waters is the greater of the two evils when compared with incidents of piracy in the same waters. ${ }^{77}$

Interestingly, in addition to cooperating with foreign militaries in fighting piracy, the Russian Navy has also cooperated directly with foreign companies to provide security for their ships, according to Sea Bulletin-Sovfreight. The Russian Navy reportedly "concluded an agreement" with at least one foreign company to provide security to vessels of Denmark's Clipper Group A/S One in the Aden Bay. ${ }^{78}$ One of this company's vessels - the CEC Future, which had Russian crew members - was seized by pirates in November 2008.

\section{Civilian Responses to Piracy}

The main element of Russian civilian agencies' response to piracy is diplomacy. It is the diplomatic channels of the Ministry of Foreign Affairs that should be employed first in cases of the seizure and illegal detention of Russian citizens on board of a vessel, according to the recent statement on piracy issued to the author by Russia's Ministry of Transportation. ${ }^{79}$ In cooperation with the owner of the seized vessel, Russian diplomats must take measures to determine the reasons behind the illegal detention and seek ways to free the citizens. ${ }^{80}$ Only if diplomatic methods do not succeed will the Russian president exercise his powers to issue an executive order to conduct an antiterrorist operation outside the borders and territorial waters of the Russian Federation in line with the Federal Law on "Countering Terrorism." 81

Russian authorities rely on a number of systems to provide alerts to incidents of piracy.

All Russian vessels that conduct international voyages are equipped with devices linked to the Global Maritime Distress and Safety System. This equipment is used to send distress calls when pirates attempt or execute seizure of a vessel. ${ }^{82}$

\footnotetext{
76 "Russia and NATO Reach a New Level," Rosbalt (16 December 2009).

77 Statement issued to the author by the Russian Navy in response to written questions on Russia's response to maritime piracy and terrorism (29 March 2008).

78 "Piracy in Year 2010: Pirates Are the Only Hope," Sea Bulletin-Sovfreight (6 January 2010).

79 Statement on Russia's response to maritime piracy and terrorism by the Ministry of Transport of the Russian Federation issued to the author in response to written questions (3 April 2008).

80 Ibid.

81 Ibid.

82 Ibid.
} 
In addition, each Russian-registered vessel is required to feature the so-called "Onboard Distress Call System," which allows a crew member to notify the authorities of an emergency without announcing an onboard alert. ${ }^{83}$

All distress calls are automatically received and processed by special coordination and rescue centers, of which there are nine in Russia. Upon receiving the distress calls, these centers analyze and relay these calls for further action by the government agencies that are involved in the Federal System of Protection of Maritime Navigation from Unlawful Acts against the Safety of Maritime Navigation.

The Russian government has also introduced and operates the Victoria System of Vessel Monitoring, which relies on satellite links and the Internet to enable the global tracking of ships. The system allows its operators to conduct continuous automated tracking of vessels equipped with the Victoria equipment all over the world, twentyfour hours a day, according to the statement issued by the Ministry of Transportation. ${ }^{84}$ Not all ships are equipped with this system, however.

The incidents of piracy off Somalia have also prompted the Russian Transportation Ministry to announce plans to develop a new system of long-range identification and monitoring of Russian vessels, according to a senior government official.

"All the vessels flying the Russian flag will be connected to the network. The vessel will send identification signals several times a day. If necessary, it will be possible to immediately get in touch with the vessel and to read its coordinates," the director of the Transport Ministry's Department for State Sea and River Transport Policy Alexei Klyavin told a meeting of the ministry's board. "The main purpose of the network is to prevent seizure of vessels by pirates," he said. ${ }^{85}$

All owners of vessels registered in the Russian Federation are required to instruct captains of their ships on how to act in case of such emergencies as attacks by pirates or terrorists. $^{86}$

In compliance with the International Code on Security of Vessels and Port Facilities, every Russian vessel has its own security manual, which not only lists what security equipment the ship should carry, but also contains detailed instructions for the crew if a threat of an attack by pirates emerges.

These instructions not only prescribe precautionary measures for periods when the ship is sailing or is moored at a port, but also spell out what the crew should do after having detected an attack, how they should respond during the pirates' intrusion, and what steps they should take after the pirates' departure from the vessel. ${ }^{87}$

3 Ibid.

${ }^{84}$ Ibid.

85 "Russia to Develop System of Long-range Vessel Identification and Monitoring," ITARTASS (28 November 2008).

${ }^{86}$ Statement on Russia's response to maritime piracy and terrorism by the Ministry of Transport of the Russian Federation issued to the author in response to written questions (3 April 2008).

${ }^{87}$ Ibid. 
Every Russian sailor is supposed to be trained in countering terrorism and piracy before he joins a crew. Crews are also required to regularly conduct counter-piracy and counter-terrorism exercises. The crews are required to obtain information about the probability of pirate attacks in areas through which their routes cross, deploy additional watchmen, and constantly monitor the environment. ${ }^{88}$

Crews of Russian civilian vessels are not armed with guns, in line with International Maritime Organization regulations. ${ }^{89}$

Their arsenals typically include only truncheons and handcuffs, according to reports in the Russian press. In comparison, some of the crews of Chinese civilian ships have had not only submachine and machine guns at their disposals, but even grenade launchers. $^{90}$

The standard operational procedures ban Russian crews from offering resistance or provoking violence when attacked by pirates. ${ }^{91}$ But the crews can and are encouraged to deny pirates access by maneuvering and locking doors. Such tactics do sometimes pay off. In February 2003, pirates attempted to seize the Primorye Sea Shipping Line's tanker Monneron en route from Saudi Arabia to Kenya off the Somali coast. The pirates fired at the tanker using automatic weapons as well as grenade launchers, but the crew managed to deny them any possibility to board the ship, and the pirates had to abort their attack after an hour. In April 2005, the Murmansk Maritime Company's passenger ship Tim Bak was attacked by two fast boats off the same Somali coast en route from Saudi Arabia to Tanzania. The pirates, who were armed with automatic weapons and grenade launchers, opened fire on the passenger ship. Again the attack fell flat; this time, the crew locked themselves in and sailed on, even though the pirates fired grenades at the ship. The pirates failed to board this ship, and the only casualty of the incident was the captain, who died of a heart attack several hours later.

While they are not allowed to provide guns to crews, Russian ship owners are encouraged to acquire and install additional equipment designed for the early warning and detection of attacks, the identification of potentially dangerous vessels, and the prevention of boarding by pirates, such as the Active Denial System and Long Range Acoustic Devices, according to the Ministry of Transportation statement. ${ }^{92}$

88 Ibid.

89 Ibid.

90 Yegor Kholmogorov, "Piraty XXI Veka: Molchit Zakon, Tsarit Zakhvat," Mayak radio station (23 May 2006); transcript available at http://old.radiomayak.ru/interview/06/05/23/ 49299.html.

91 Ibid.

92 Statement on Russia's response to maritime piracy and terrorism by the Ministry of Transport of the Russian Federation issued to the author in response to written questions (3 April 2008). 


\section{Piracy, Organized Crime, and Terrorism: A Dangerous Nexus}

Russia has no endemic actors permanently involved in piracy. Most of the incidents of piracy and armed attacks involving Russian ships and/or crews have been blamed on foreign groups, and have taken place far from Russia's territorial waters.

Nevertheless, in addition to the Arctic Sea incident, there have been a number of incidents registered in Russia's own waters that featured methods often used by pirates. For instance, residents of some of the settlements located on the shores of Lake Baikal would board fishing ships and seize part of the catch, threatening the crew with rifles, often making off with fish worth an average of USD 2,000-3,000, according to a recent report in the Russian press. ${ }^{93}$

Some of those robbed chose not to report the incident to the police because their catch had been illegal in the first place, according to the report.

The Caspian Sea has seen incidents where residents of Russia's volatile province of Dagestan would roam the waters in fast boats armed with submachine guns to rob freighters operated by businesses based in neighboring Azerbaijan, according to newspaper reports. ${ }^{94}$ In one operation, Kazakh Coast Guard units detected twenty such fast boats, and intercepted three of them near the Tyub-Kurgan Cape in 2007. Newspapers reported that one of the boats operated by residents of Dagestan had two large-caliber machine guns and a grenade launcher on board. ${ }^{95}$ The detained individuals confessed to robbing ships and were charged accordingly.

In another incident, citizens of Russia and Azerbaijan joined forces to raid small Caspian Sea islands belonging to Kazakhstan, arriving in boats and armed to rob employees of the Kazakh meteorological service, according to Kazakh police sources.

Organized crime groups in Russia's Far East routinely target fishing poachers to collect a protection fee from them, according to newspaper reports. ${ }^{96}$ About one-fourth of Russian ships leaving Russia's Far Eastern ports to fish in the Pacific Ocean every day operate in violation of Russian laws. The local criminal groups collect fees from such poachers. If the latter refuse to pay, then the criminals use fast boats to pursue and board such fishing vessels to collect their protection money. One local criminal boss reportedly also routinely collected a protection fee from ships transporting secondhand cars from Japan to Russia by pursuing and boarding them in the Pacific Ocean. ${ }^{97}$ In an ironic twist of fate, one of the organized crime groups based in the far eastern region of Primorsky Krai was extorting in 2009 anywhere between USD 600 and 2,000 per person from crew members of the Russian Navy's Pacific Fleet upon their return from the anti-piracy patrols in the Gulf of Aden, according to reports in the Russian media. The group, which was busted in the fall of 2009 , included one former naval

\footnotetext{
93 "Piraty Rossiiskikh Morei," Versiya v Pitere (22 December 2008).

94 Ibid.

95 Ibid.

96 Ibid.

97 Ibid.
} 
serviceman who knew what bonuses these crew members had been paid for the anti-piracy missions. ${ }^{98}$

In spite of the absence of endemic piracy in Russia's territorial waters, pirates in general could still pose a security threat to Russian assets that would transcend the boundaries of piracy per se.

This would occur if foreign pirate groups establish ties with either internal or international terrorist groups that are motivated and capable of targeting Russian assets. To date, there is no publicly available information about such ties.

The absence of such links conforms to a recent RAND study suggesting that, while terrorists and organized crime figures are collaborating on land, there is little evidence that terrorists and piracy syndicates are collaborating at sea. ${ }^{99}$ According to the study, their interests may conflict and thus prevent collaboration, since pirates depend on steady commercial activities in the waters they operate, while terrorists often seek to cause maximum damage and disruption.

But some terrorist and militant groups, such as the Sri Lankan Liberation Tigers of Tamil Eelam (LTTE), have been involved in classical organized crime activities, such as illicit trafficking, to finance their activities. At its peak, LTTE had a fleet of ten ocean-going freighters. ${ }^{100}$ And while a long-term alliance of terrorists and pirates may indeed be unlikely, as the RAND study suggests, pirates can still sell their mariner and hijacking skills and capabilities to terrorists for at least one attack, especially if the latter keep the pirates in the dark about their real attentions or stage the attack outside the area where the pirates make their living.

As stated above, the Russian military believes that the "line between piracy and maritime terrorism has become blurred," ${ }^{101}$ and this belief is grounded in the rather alarming development of ties between pirates and international terrorist networks that maintain contacts with and have assisted terrorist groups inside Russia.

One such network is Al Qaeda. It maintains close ties with Somalia's al-Shabaab Islamist militia ${ }^{102}$ (which has been actively engaged in piracy ${ }^{103}$ ) as well as with terrorist networks in Russia's North Caucasus.

98 “Piracy Fighters Were Robbed Right on Shore," Ryba (6 October 2009).

99 Michael D. Greenberg, Peter Chalk, Henry H. Willis, Ivan Khilko, and David S. Ortiz, Maritime Terrorism, Risk and Liability (Santa Monica, CA: The RAND Center for Terrorism Risk Management Policy, 2006).

${ }^{100}$ Ali M. Koknar, "Maritime Terrorism: A New Challenge for NATO," Energy Security, prepared by the Institute for the Analysis of Global Security (24 January 2005); available at www.iags.org/n0124051.htm.

${ }^{101}$ Statement to the author by the Russian Navy in response to written questions on Russia's response to maritime piracy and terrorism (29 March 2008).

102 "The recent bombings in Somalia may have been meant, at least in part, to strengthen bona fides with Al Qaeda's senior leaders. A merger between al-Shabaab and Al Qaeda could give Somali extremists much-needed funding, while Al Qaeda could claim to be reestablishing its operations base in East Africa, according to then CIA director Michael Hayden. "CIA Chief says Al Qaeda Still Greatest Threat, Bin Laden Isolated but Network Spreading Influence in Africa, Mideast," AP (13 November 2008). 
In addition to ties with Somali groups engaged in piracy, Al Qaeda itself has owned and/or controlled somewhere between fifteen and twenty-three freighters sailing in the Mediterranean Sea and Indian and Pacific Oceans, according to estimates by the U.S. and Norwegian intelligence agencies. ${ }^{104} \mathrm{Al}$ Qaeda has also successfully carried out acts of maritime terrorism. Operatives and/or allies of Al Qaeda have been responsible for the bombing of the U.S. Navy's Cole warship in the port of Aden and of France's Limburg tanker. The network has also designed attacks on a wide range of Western maritime targets, including military vessels, oil tankers, and cruise ships, according to information from Abd Al Rahman al Nashiki, the alleged organizer of both attacks and an Al Qaeda member. ${ }^{105}$

Links between North Caucasus-based terrorist networks and Al Qaeda have been well documented. Osama bin Laden has been actively involved in terrorism and the insurgency in North Caucasus since 1995, sending Al Qaeda agents to the North Caucasus and sponsoring Chechen rebels, according to a declassified U.S. intelligence report. ${ }^{106}$

Bin Laden sent the Jordanian-born Al Qaeda warlord Khattab and nine instructors to Chechnya in 1995 to set up terrorist training camps, according to a U.S. Defense Intelligence Agency report. Bin Laden met several times in 1997 with militant Islamists from Chechnya and Dagestan and "settled the question of cooperationagreeing to provide 'financial supplies' to Chechen militants," according to the report. ${ }^{107}$ U.S. intelligence agencies once estimated that as many as one hundred Al Qaeda militants were present at the now defunct bases operated by Chechen rebels in Georgia's troubled Pankisi Gorge region. The FBI also believes that such ties have existed: "Although Al Qaeda functions independently of other terrorist organizations, it also functions through some of the terrorist organizations that operate under its um-

103 "The entire Somali coastline is now under control of the Islamists," Andrew Mwangura, head of the East African Seafarers' Assistance Program, told Reuters in an interview. "According to our information, the money they make from piracy and ransoms goes to support al-Shabaab activities onshore." "Piracy Ransoms Funding Somalia Insurgency," Reuters (24 August 2008).

104 "What Al Qaeda Can Do with A Terror Navy," World Net Daily (October 2003); cited in Koknar, "Maritime Terrorism: A New Challenge for NATO."

${ }^{105}$ Koknar, "Maritime Terrorism: A New Challenge for NATO."

${ }^{106}$ The document was released by Judicial Watch, a U.S. public corruption watchdog, in 2004.

107 "U.S. Report Links Bin Laden, Rebels," Moscow Times (22 November 2004). In addition to Khattab, of several senior figures in Chechen-based groups probably tied to Al Qaeda was Abu Dzeit, a Kuwaiti national and suspected Al Qaeda liaison who was killed by Russian security forces in February 2005. A video purportedly showing Basayev preparing for the 2004 Beslan school attack shows Abu Dzeit sitting next to Basayev. "Video Apparently Shows Basayev Planning Attack," Associated Press (1 September 2005). In addition, a Jordanian named Abu Majahid, who the FSB believes to have arrived in Chechnya in 1992 and served as an emissary of Al Qaeda, was the organizer of foiled chemical attacks in the cities of the North Caucasus in 2005. "FSB Says Major Terror Attacks Foiled," Moscow Times (6 May 2005). 
brella or with its support, including: the Al-Jihad ... and the Chechen region of Russia." 108

Of all agents plotting and executing acts of terror in Russia, North Caucasus-based terrorist networks have the strongest motivation and capabilities for acts of maritime terrorism, possibly of catastrophic proportions. These networks have bombed a Coast Guard residential complex and a parade at a Caspian Sea town, killing dozens; they have plotted to hijack one atomic submarine and claimed responsibility for sinking another, while their supporters seized a vessel with Russian passengers on board and threatened to blow it up.

North Caucasus-based terrorist networks can count on Al Qaeda and its allies that have engaged in piracy to share expertise with them if they decide to plot and execute an act of maritime terrorism. Mariner skills, which pirates possess, would be vital for the successful implementation of such terrorism scenarios as the seizure and explosion of a tanker filled with poisonous chemicals in a major port, or the seizure of a large passenger ship, with subsequent execution of passengers.

\section{Conclusion}

As stated above, maritime shipments account for 60 percent of Russia's foreign trade, but the number of piracy-related incidents involving Russian-registered vessels remains low.

The Russian Navy has referred to the fact that most Russian-owned ships fly foreign flags, while vessels carrying Russian flags account only for 4 percent of Russia's foreign trade shipments, when responding to public criticism that the navy is not doing enough to tackle the threat of piracy. ${ }^{109}$ Indeed, the share of Russian-owned shipping vessels carrying foreign flags increased from 18.4 percent in 1992 to 64.2 percent in $2009 .{ }^{110}$ As of 2009 , the number of maritime and river shipping vessels defined by the head of the Federal Agency for Maritime and River Transportation, Alexander Davydenko, as having "the right to carry the Russian flag" totaled 3,617, including 2,938 vessels registered in the State Registry of Ships. Of these ships, 318 vessels had deadweight of 1,200 tons.

There is also a total of some 2,800 smaller Russian fishing vessels, with catches of between 300-400 tons of fish annually. The number of larger Russian fishing vessels that would pass through seas affected by piracy is quite low, however, as most of them stay in littoral waters and freshwater. At the moment, Russia's fishing fleets are "all but

108 James T. Caruso, Acting Assistant Director, Counter Terrorism Division, Federal Bureau of Investigation, "Statement for the Record on Al Qaeda International," before the Subcommittee on International Operations and Terrorism, Committee on Foreign Relations, United States Senate, Washington, D.C., 18 December 2001; available at www.fbi.gov/congress/ congress01/caruso121801.htm.

${ }^{109}$ Statement to the author by the Russian Navy in response to written questions on Russia's response to maritime piracy and terrorism (29 March 2008).

110 "Interview with head of the Federal Agency for Maritime and River Transportation Alexander Davydenko," Morskaya Politika Rossiii (December 2009). 
gone from the World Ocean," according to Andrei Krainyi, head of the Federal Fishing Agency. There are, however, Russian fishing vessels currently fishing off the coasts of Africa, according to Krainyi. ${ }^{111}$

As was stated above, a simple comparison of the number of Russian commercial ships (which adds up to a total of some 6,400) with the number of piracy incidents involving Russian crews and vessels helps to explain the fact that Russian authorities did not employ any naval assets to fight piracy until the fall of 2008. Once they were deployed on counter-piracy missions, Russian Navy warships escorted more than 300 ships in 2008-09 in the Gulf of Aden and Horn of Africa area.

In comparison, from late 2008 to late 2009, the Chinese Navy escorted a total of 1,100 ships in the Gulf of Aden. ${ }^{12}$ The difference is rooted in the fact that China's fishing and shipping volumes greatly exceed Russia's. In 2008, China had 250,000 ships registered, at 96 million gross tons, of which 20,925 were ocean ships, weighing 44 million tonnes; the other 230,000 ships, serving on rivers, totaled 52 million tonnes. ${ }^{113}$ In addition, China topped the world in terms of cargo handling capability in 2008. ${ }^{114}$ China is also the world's largest producer and exporter of fish. ${ }^{11}$

The financial difficulties experienced by the Russian Navy in the aftermath of the break-up of the Soviet Union also help to explain this lack of response.

Due to economic hardships, Russia's military presence across the world was scaled back significantly in the $1990 \mathrm{~s}$ - a move that would have prevented a proactive approach to fighting piracy even if the Russian leadership had decided that piracy was a high-priority threat.

The low level of public awareness of and interest in the issue in Russia is another factor in Russia's late response to piracy, although this is beginning to change.

In what is perhaps an ironic twist, some of Russia's legitimate businesses, which are located thousands of miles away from international piracy hotbeds, have even benefited from piracy. "The Port of Arkhangelsk Thanks Somali Pirates" was the headline on a news item on the web site of the Russian publication Sea BulletinSovfreight, according to one report in the Russian media. ${ }^{116}$ The story welcomed the

111 "Russia's Failure to Catch,” Expert (27 November 2009).

112 "Ships of the People's Liberation Navy Escorted 1,100 Vessels in the Gulf of Aden," Xinhua News Agency (14 November 2009).

${ }^{113}$ China's unified registration system recorded a total of 133,392 ships in 2008, which results in the sum of 250,000 ships registered in China. "Registered Ships in China Reach 96 million GT in 2008," Baird Maritime (10 March 2009).

${ }^{114}$ China's development of sixteen 100-million-tonne capacity ports by the end of 2008 made it the first nation in the world to achieve such cargo handling capability, with the opening of fresh capacity to Tangshan and Lianyungang ports. "China Tops World Cargo Handling Capability," Baird Maritime (10 March 2009).

115 "Engaging Oceania," Naval War College Review (1 January 2010).

${ }^{116}$ Marina Ledyaeva, “Morskie Perevozki," Pravda Severa (12 December 2008). 
re-routing of coal shipments to Norway via this northern Russian port because of piracy incidents off the African coast. ${ }^{117}$

However, several years of economic growth before the 2008-09 economic crisis allowed the Russian government to steadily increase its defense expenditures, extending their conventional forces' reach, while Russia's foreign policy ambitions also grew in scope and scale. After faltering in 2009, the Russian economy appears poised for a year of modest growth in 2010, although most Russian economists concur that its GDP will not reach the pre-crisis level until 2012-13.

Just as important as the boom-driven rise in defense spending was the fact that, as the economy grew, so did Russian companies and individuals' activities abroad, including both shipping and fishing. Thanks to the expansion of the media industry's reach, and the globalization of news in general, the Russian public's awareness of piracy incidents in general, and particularly those involving Russian citizens, grew as well.

Moscow's decision to send Russian Navy vessels to patrol the waters off Somalia, thus re-establishing a naval presence in the area, came as a response to this trend. It may also have been prompted by Russia's desire to re-establish itself as a global power, as well as by Russia's renewed interest in the minerals-rich African continent, into which Russian aluminum and oil giants have been making steady inroads (with strong encouragement from the Kremlin).

Russia's more active responses to piracy, as evidenced by the deployment of warships to the East African coast and the inclusion of fighting piracy in the new 2010 Military Doctrine's list of the Russian armed forces' peacetime missions, might also be signs of Moscow's foresight in the sphere of preventive security. The Russian government plans a number of measures, including fiscal stimulus, to entice thousands of Russian vessel owners whose ships are currently flying foreign flags to re-register under the Russian flag. Among other measures, the authorities have promised to introduce simplified taxation regimes at twelve ports to lure Russian vessel owners to carry the Russian flag. Should the Russian authorities succeed in attracting Russian owners to register their vessels in Russia and fly Russian flags, then the volume of maritime shipment by Russian-registered vessels will grow, and so too will the number of attacks on Russian-flagged ships, which may prompt Russian authorities to take a more proactive approach in both their military and civil responses to piracy. The adoption of such a proactive stance will also become more likely if the Russian fishing industry continues to grow. Russia's fishing agency chief Krainyi estimated that the fishing industry grew by 9 percent in 2009. ${ }^{118}$ In comparison, the country's GDP declined by some 9 percent in that same year, due to the global economic crisis.

${ }^{117}$ The news item said Norway's Finnfjord AS has decided to change the route of importing coal from China after one of the transporting ships was seized and kept by Somali pirates for fifty-one days. The new route went via the railroad from China to Russia's northern port of Arkhangelsk, and then on by sea to Norway. Marina Ledyaeva, "Morskie Perevozki," Pravda Severa (12 December 2008).

118 "Russia's Failure to Catch." 
Obviously, the handful of warships that Russia has contributed to the Combined Maritime Forces' Combined Task Force 151 is not enough. The CTF should operate with at least one hundred warships to effectively fight piracy, former Russian Navy Commander Vladimir Masorin has estimated. ${ }^{119}$ The Russian Navy should continue to revive its ocean-going capacity if Moscow wants to be able to have its own warships deter piracy threats against Russian commercial ships, as befits a leading maritime power.

The deployment of more Russian warships to waters off the African coast can help to decrease piracy, but this threat will not be eliminated as long as the major powers limit their counter-piracy activities to the sea.

Russia and other responsible nations should pursue the pirates on shore to dismantle their bases while also initiating changes in the international laws that would remove the aforementioned legal hurdles that constrain effective countering and prosecution of piracy.

Russia and other responsible nations should not only target pirates' bases on shore, but should also act to address the root causes of the problem, which lie in poverty, lawlessness, and other vestiges of a failed state.

Addressing these root causes would require first enforcing peace in Somalia, and then an extended exercise in nation building - something to which neither Russia nor the other great powers are currently willing to commit, after the failure of the international operation in Somalia that ended with the withdrawal of UN forces in 1995.

The Russian leadership should also remain alert in order to prevent the establishment of ties between groups engaged in both piracy at sea and insurgency on land and terrorist groups seeking to attack Russia's homeland. This is the least that Russian policy makers can do, even if the current economic crisis significantly diminishes Russia's capability to conduct a far-reaching foreign and security policy.

119 “New Naval Task Force Won’t Eradicate Piracy - Expert,” ITAR-TASS (12 January 2009). 


\section{Bibliography}

A Group of Pacific Fleet Ships Returned to Vladivostok After Patrolling the Gulf of Aden. ITAR-TASS, 2009.

Baker, Luke. "Navy Commander Admits: No Rules on Somalia Pirates." Reuters (2008).

Beginning of Meeting with Navy Servicemen Who Participated in Anti-Piracy Operations off the Coast of Somalia. Kremlin.ru, 2009.

Boarders Eat Round Pacific Fleet. RIA Prima Media (2009).

Bownes, Glenn. "Russia Calls for 'Ground Operation' to Crush Piracy." Cape Times (2008).

Chornaya Metka Ot Spetznaza. Rossiiskaya Gazeta (2008).

CIA Chief says Al Qaeda Still Greatest Threat, Bin Laden Isolated but Network Spreading Influence in Africa, Mideast. AP, 2008.

Costa, Antonio Maria. "Piracy Must be Defeated in Courts, Ports and Banks, not Just at Sea." Lloyd's List (2009).

Deputy Prosecutor General Alexander Zvyagintsev: An International Tribunal for Piracy Is Needed. Izvestia (2009).

Dygalo, Igor. "The Russian Navy Calls on All Countries to Unite Against Piracy." Izvestia (2008).

Engaging Oceania. Naval War College Review (2010).

Fateful Tuna: Somali Pirates Have Kidnapped a Record Number of Russians. Novye Izvestia (2009).

FSB Says Major Terror Attacks Foiled. Moscow Times (2005).

Gortney, William. "Process for Capture, Accountability Remains Piracy's Challenge." Inside the Navy 22, no. 3 (2009).

Greenberg, Michael D., Peter Chalk, Henry H. Willis, Ivan Khilko, and David S. Ortiz. Maritime Terrorism, Risk and Liability. Santa Monica, CA: The RAND Center for Terrorism Risk Management Policy, 2006.

Interview with head of the Federal Agency for Maritime and River Transportation Alexander Davydenko. Morskaya Politika Rossiii (2009).

Kellerhals, Jr., Merle D.. "UN Forms Group to Coordinate Actions against Maritime Piracy." All Africa (2009).

Kholmogorov, Yegor. Piraty XXI Veka: Molchit Zakon, Tsarit Zakhvat. Mayak radio station, 2006.

Koknar, Ali M.. Maritime Terrorism: A New Challenge for NATO. Energy Security, by the Institute for the Analysis of Global Security, 2005.

Kuda Idyot Voyennyi Flot. Vlast (2008). 
Last Arctic Sea Sailors Return to Russia. Agence France Presse, 2009.

Ledyaeva, Marina. "Morskie Perevozki." Pravda Severa (2008).

Meeting with Transport Ministers from 24 Countries. Kremlin.ru, 2009.

Military Doctrine of the Russian Federation. Kremlin.ru, 2010.

New Naval Task Force Won’t Eradicate Piracy - Expert. ITAR-TASS, 2009.

Osborn, Andrew. "World News: Moscow Will Boost Defense Spending to \$50 Billion - Con-flict in Georgia Exposed Deficiencies of Aging Arsenal." Wall Street Journal (2008).

Pacific Fleet Servicemen Implemented the Entire Program of Combat Training in 2009. RIA Vesti, 2009.

Pervyi Boi Admirala. Rossiiskaya Gazeta (2009).

Piracy Fighters Were Robbed Right on Shore. Ryba (2009).

Piracy in Year 2010: Marines Are the Only Hope. Sea Bulletin-Sovfreight (2010).

Piracy in Year 2010: Pirates Are the Only Hope. Sea Bulletin-Sovfreight (2010).

Piracy Ransoms Funding Somalia Insurgency. Reuters, 2008.

Pirate Attack in Gulf of Aden Foiled by Russian Warship. St. Petersburg Times (2009).

Piraty Rossiiskikh Morei. Versiya v Pitere (2008).

Registered Ships in China Reach 96 million GT in 2008. Baird Maritime, 2009.

Russia and NATO Reach a New Level. Rosbalt (2009).

Russia Orders 70 Strategic Nuclear Missiles by 2011: Report. AFP, 2008.

Russia Sends More Warships to Fight Somali Pirates: Report. AFP, 2009.

Russia to Develop System of Long-range Vessel Identification and Monitoring. ITARTASS, 2008.

Russia's Failure to Catch. Expert (2009).

Russian Base for Fighting Pirates. Nezavismoye Voyennoye Obozrenie (2009).

Russian Cruiser Pyotr Veliky Leaves India. RIA Novosti (2009).

Russian Cruiser 'Pyotr Veliky' Leaves India. RIA Novosti (2009).

Russian Embassy in Kenya to Give Consular Support to Faina Sailors. ITARTASS, 2009.

Russian Federation Made Concrete Proposals to NATO on Fighting Pirates. Rosbalt (2009).

Russian Navy Arrests Eight 'Pirates' who Seized the Cargo Ship 'Arctic Sea'. Daily Telegraph (2009). 
Russian Navy Denies Somalia Mission Scurvy Claims. RIA Novosti, 2009.

Russian Navy Servicemen Got Rid of Pirates. Tyumenskaya Linia (2009).

Russian, British Ships Repel Somali Pirate Attack. AP, 2008.

Russian, Indian Warships Escort Commercial Ships off Somali Coast. RIA Novosti, 2009.

Servicemen of Pacific Fleet Found an Effective Method of Fighting Pirates. RIA Prima Media, 2009.

Ships of Russian Navy Will Maintain a Permanent Presense Off the Coast of Somalia. Fontanka.ru, 2009.

Ships of the People's Liberation Navy Escorted 1,100 Vessels in the Gulf of Aden. Xinhua News Agency, 2009.

Somali pirate attacks up 75 percent this year. AP, 2008.

Somali Pirates Will be Tried in Russia. Nakanune.ru, 2009.

U.S. Report Links Bin Laden, Rebels. Moscow Times (2004).

What Al Qaeda Can Do with A Terror Navy. World Net Daily, 2003.

Where Ours Have Not Gone Missing. Kommersant (2000). 